\title{
A New Mini Box Corer for Sampling Muddy Bottoms in Antarctic Shallow Waters
}

\author{
Carlos Alejandro Echeverría ${ }^{1 *}$, Helena Passeri Lavrado ${ }^{2}$, Lúcia Campos ${ }^{3}$ and Paulo Cesar \\ de Paiva ${ }^{4}$ \\ ${ }^{1}$ Laboratório de Pesquisas Costeiras e Estuarinas; Universidade Federal do Rio de Janeiro; Hangar da Ponta do \\ Catalão; Rio de Janeiro - RJ - Brasil. ${ }^{2}$ Laboratório de Benthos; Departamento de Biologia Marinha; Universidade \\ Federal do Rio de Janeiro; Rio de Janeiro - RJ - Brasil. ${ }^{3}$ Laboratório de Echinodermata; Departamento de \\ Zoologia; Universidade Federal do Rio de Janeiro; Rio de Janeiro - RJ - Brasil. ${ }^{4}$ Laboratório de Polychaeta; \\ Departamento de Zoologia; Universidade Federal do Rio de Janeiro; Rio de Janeiro - RJ - Brasil
}

\begin{abstract}
A new Mini Box Corer (MBC-GEAMB) was developed for bottom sampling in Antarctic shallow waters down to 100 $m$ depth from a small vessel. It consists of a detachable stainless steel box with a total sampling area of $0.0625 \mathrm{~m}^{2}$, and a closing arm with a detachable blade without an external frame. MBC allowed stratified bottom sampling and good quality samples comparable to those obtained through diving. A comparison between the MBC-GEAMB and a $0.056 \mathrm{~m}^{2}$ van Veen grab (VV) was undertaken for the benthic macrofaunal composition in Admiralty Bay, King George Island (Antarctica). MBC and VV samples were taken from three depths (20,30 and 60m) in two sites. Total densities sampled with the MBC were up to 10 times higher than those obtained with van Veen grab. VV samples might lead to faunistic abundance underestimation compared to the MBC samples. Besides, MBC showed a higher performance on discriminating different sites as regards total macrofaunal density. It is suggested that MBC could be employed as an efficient remote sampling device for shallow-waters where direct sampling by SCUBA was not advisable.
\end{abstract}

Keywords: Mini box-corer, Antarctica, Benthos, sampling

\section{INTRODUCTION}

Remote quantitative sampling gears such as vanVeen, Eckmann, box corers and multicorers have been used for a long time to collect benthic invertebrates from shallow and deep sea soft sediments (Holme and McIntyre, 1984), where hand collection is difficult or even impracticable. Sampling gears limitations may include small sampling area, physical disturbance of sediments, bow-wave effects, lack of surface fine-grained sediments retention, penetration depth, and physical characteristics of the sediment type (e.g. particle size and degree of consolidation) (Eleftheriou and Holme, 1984, Byliard et al, 1987, Pohle and Thomas, 1997). Core samplers such as box corers and multicorers are generally used for mud, silt and other soft sediments, where water/sediment interface studies are needed and information on sediment vertical structure is important (Eleftheriou and Holme, 1984). Disadvantages are their large size and weight,

* Author for correspondence: caecheve@acd.ufrj.br 
generally requiring large vessels facilities for deployment (Eleftheriou and Holme, 1984, Bilyard et al, 1987). Hand-held corers can avoid some of these problems (Fonseca et al, 2004; Santos Furtado et al, 2002) but are restricted to SCUBA-diving depth. Previous benthic sampling surveys in Admiralty Bay through scuba diving were restricted to depths down to ca. 25m (Jazdzewski, 1998, Skorowski et al., 1998, Nonato et al, 2000). An integrated sampling strategy involving a multidisciplinary program (CNPq-Proantar-Rede 2) in Admiralty Bay, King George Island, Antarctica, has been implemented in order to collect sediment and water at the beginning and end of each austral summer, to differentiate natural fluctuations within benthic communities from those caused by anthropogenic impacts. For this purpose, a new remote sediment sampling device has been designed.

\section{MATERIAL AND METHODS}

Mini Box Corer (MBC-GEAMB) description: The MBC-GEAMB was built with $5 \mathrm{~mm}$ stainless steel plates. It consisted of a sampling box $(25 \times 25 \times 55$ $\mathrm{cm}$, sampling area $0.0625 \mathrm{~m}^{2}$ ) (Fig. 1.2), an upper structure (Fig. 1.1) that fits on top of the box, and a mobile arm (Fig 1.3) with a detachable blade (Fig. 1.4). The release system has a hook with a climbing tape (fig 1.5), and the deployment velocity was controlled by a climbing "eight" brake (Fig 1.6). Sampling box was attached to the upper structure (with have two mobile windows to minimize the bow wave effect) by four rapid release locks. There was an axis on either side of the box (Fig 1.2.B) where the arm blade fits (Fig 1.3.G). The axis sockets, on both sides, are elongated allowing the blade to close freely in a relatively distant $(1-2 \mathrm{~cm})$ position from the lower portion of the sampling box (fig 1.4). Once closed, the blade was pushed against the sampling box during elevation through the cable. A $10-\mathrm{mm}$ nylon cable could be used for the equipment deployment. The cable ran through an opening and a pulley fit in the upper structure close to the axis connecting point (Fig 1.1.D). It contoured a second pulley in the arm (Fig 1.3.H), and was tied to a transversal-supporting rod (Fig 1.1.I).

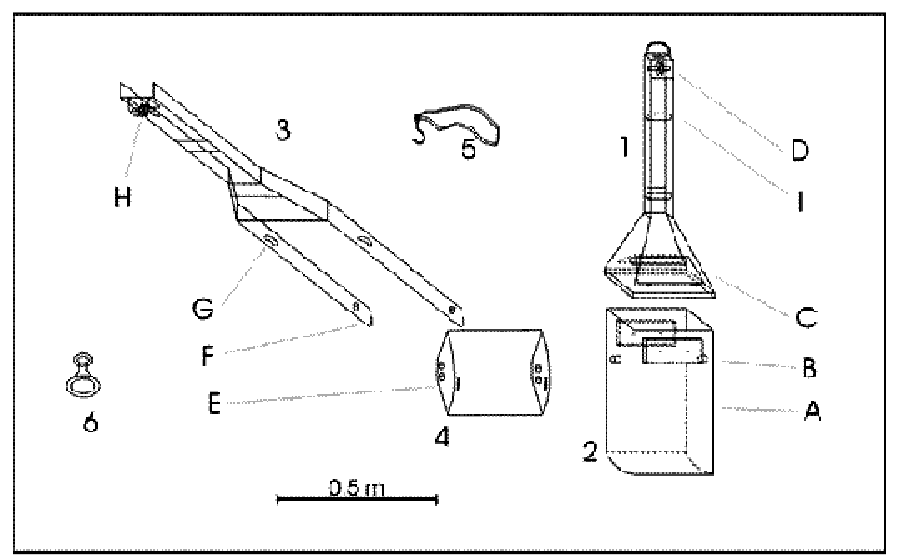

Figure 1 - Scheme of the unassembled Mini Box Corer GEAMB

This rod rested on a higher position than the arm pulley when the system was closed. The rod pushed the arm blade up when the deployment cable was tensed up, assuring the complete closing of the blade against the bottom of the sampling box (Fig 1.4), keeping it firmly closed (Fig 1.2). Once the equipment was retrieved on board, the blade could easily be released from the upper structure, the sampling box sitting on the blade was left opened, and the subsampling procedure could be carried out. The deployment procedure, from a small motor boat equipped with a 200 Kilograms (minimum) wrench, ran as follows: the hook with the climbing tape was attached to the nylon cable using a Prussic hitch. This hitch could run over the cable when the weight was not loaded, locking when the weight was over it. The cable passed through the eight climbing brake 
which was tied to a structure on the deck. The MBC-GEAMB was lowered at a constant speed in order to allow a straight vertical descent. Once the MBC-GEAMB hit the seafloor, the operator released the cable in order to disengage the hook pulling afterwards firmly avoiding the MBC to lie in the bottom. The eight brake was released and the cable was attached to the wrench that started rolling over. Once the hook on the cable reached the surface, the operator freed the Prussic hitch, and pushed the hook down along the cable. This mechanism allowed the use of a small cargo arm for deployment (Fig. 2).

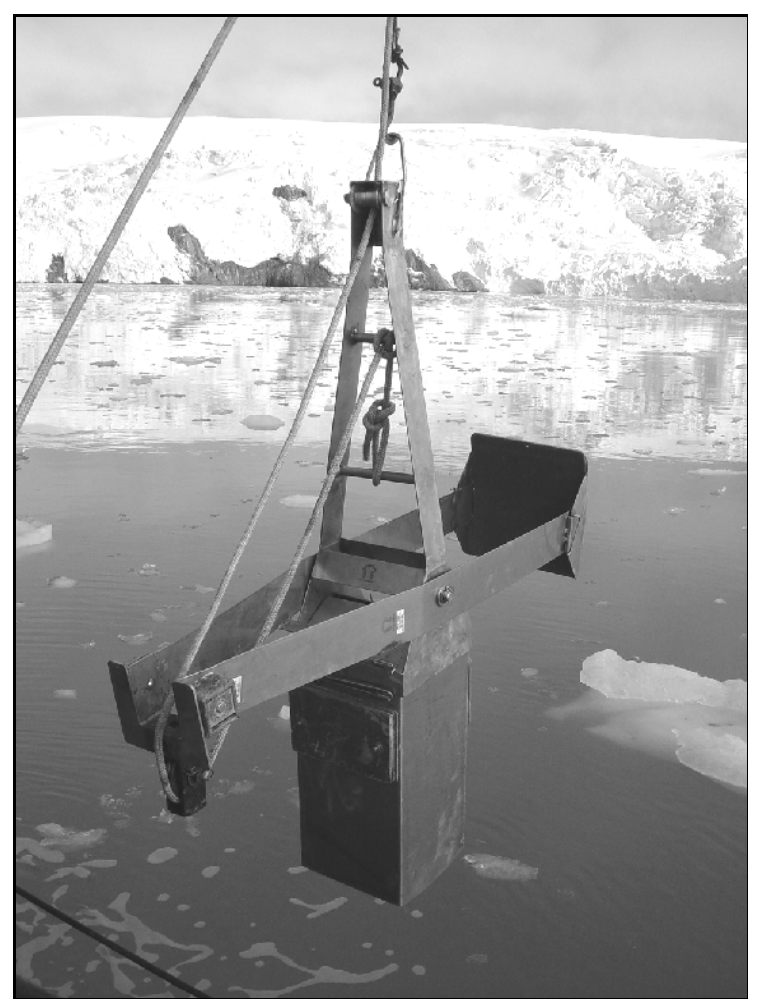

Figure 2 - Mini Box Corer GEAMB ready for deployment.

The Brazilian Antarctic Research Station "Comandante Ferraz" (EACF) is located at Keller Peninsula, Admiralty Bay, King George Island, Antarctica $\left(058^{\circ} 23.5^{\prime} \mathrm{W} ; 062^{\circ} 5.1^{\prime} \mathrm{S}\right)$. Two areas were selected for a field test: in front of EACF, and in front of the Peruvian Station Machu Picchu (MP) (fig 3). Sediment samples were taken with the MBC-GEAMB $\left(0.0625 \mathrm{~m}^{2}\right)$ and a van Veen grab $(0.056 \mathrm{~m} 2)$ over a transect from the shore, in 3 stations at 20,30 and 60 meters depth in both areas (CF and MP, Fig. 3). The MBC samples were subsampled using three $0.0078 \mathrm{~m}^{2}$ PVC cylindrical corers and sliced to $10 \mathrm{~cm}$ in the sediment (i.e., 0-2, 2-4, 4-6, 6-8 and 8-10 cm depth). All samples were sieved through a $0.5-\mathrm{mm}$ sieve. Specimens were identified at Taxon level: Polychaeta, Oligochaeta, Nematoda, Cumacea, Gammaridea, Tanaidacea, Ostracoda and Bivalvia. Data normality and homogeneity of variances were tested. Owing to the low number of replicates, tests were not conclusive for all comparisons. Nevertheless, we opted for a OneWay ANOVA due to its recognized robustness to non-normality assumptions (Underwood, 1997). Multiple comparisons were performed by Tukey post-hoc test. 


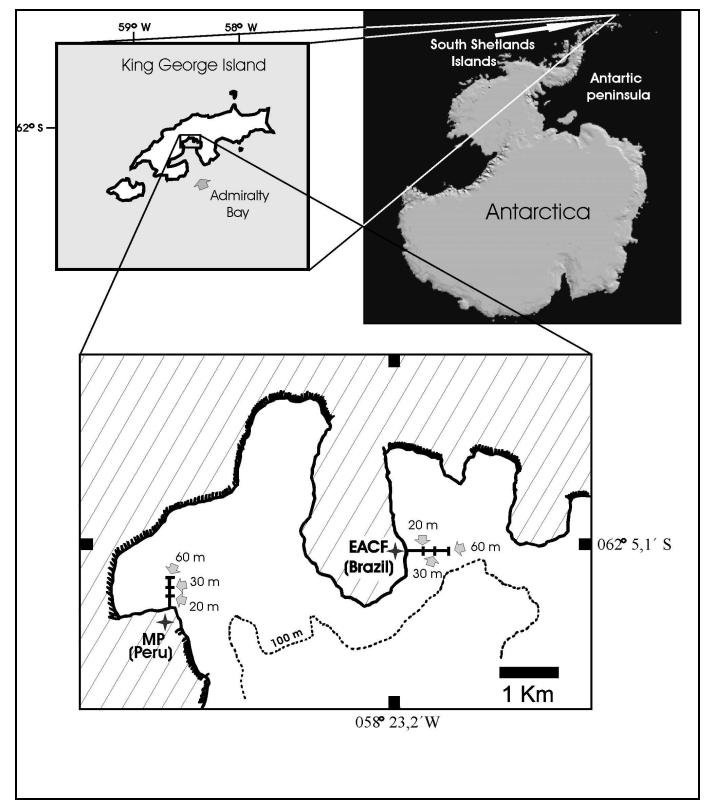

Figure 3 - Sampling stations in Admiralty Bay, King George Island, Antarctica. MP: Machu Picchu Peruvian Research Station; EACF: Brazilian Antarctic Research Station "Comandante Ferraz".

\section{RESULTS}

The maximum density observed with the van Veen was 563 ind.0.056 $\mathrm{m}^{-2}$ at $30 \mathrm{~m}$ depth in MP, and the minimum was 36 ind. $0.056 \mathrm{~m}^{-2}$ at $60 \mathrm{~m}$ depth in CF (Table 1). The faunal densities registered for the MBC samples diminished as depth increased in both sampling areas (Table 2). The maximum density observed with the MBC samples was 4.421 ind $0.056 \mathrm{~m}^{-2}$ at $20 \mathrm{~m}$ in $\mathrm{CF}$ with a minimum of 174 ind. $0.056 \mathrm{~m}^{-2}$ at $60 \mathrm{~m}$ depth in CF (Table 2).

Table 1 - Van Veen $\left(0.056 \mathrm{~m}^{2}\right)$ densities for taxonomic groups (X: mean; S: standard error; CV: coefficient of variance; n: 4). CF: Comandante Ferraz station; MP: Machu Picchu station.

Polychaeta Nematoda Oligochaeta Cumacea Gammaridae Isopoda Tanaidacea Bivalvia Gastropoda Ostracoda Others Total CV

\begin{tabular}{|c|c|c|c|c|c|c|c|c|c|c|c|c|c|c|}
\hline \multirow{2}{*}{$\mathrm{CF} 20 \mathrm{~m}$} & $\mathrm{X}$ & 379.67 & 8.33 & 49.67 & 98.67 & 15.33 & 1.00 & 0.00 & 58.67 & 17.33 & 1.00 & 1.33 & 631 & \\
\hline & SE & 31.21 & 7.57 & 78.31 & 68.41 & 11.37 & 1.73 & 0.00 & 101.61 & 5.03 & 1.00 & 1.53 & 332,7 & 52.73 \\
\hline \multirow{2}{*}{$\mathrm{CF} 30 \mathrm{~m}$} & $X$ & 354.00 & 1.00 & 8.75 & 3.25 & 8.75 & 0.25 & 0.00 & 71.50 & 2.75 & 0.25 & 1.75 & 452.25 & \\
\hline & SE & 308.64 & 1.15 & 13.57 & 2.50 & 13.52 & 0.50 & 0.00 & 131.23 & 4.27 & 0.50 & 2.36 & 390.8 & 86.41 \\
\hline \multirow{2}{*}{$\mathrm{CF} 60 \mathrm{~m}$} & $X$ & 23.50 & 1.50 & 0.75 & 2.50 & 1.75 & 0.00 & 0.00 & 1.00 & 3.25 & 1.25 & 1.00 & 36.5 & \\
\hline & SE & 27.16 & 1.91 & 0.96 & 1.29 & 1.71 & 0.00 & 0.00 & 0.82 & 4.03 & 2.50 & 2.00 & 30.49 & 83.53 \\
\hline \multirow{2}{*}{ MP $20 \mathrm{~m}$} & $X$ & 204.80 & 4.20 & 22.00 & 17.20 & 16.40 & 0.00 & 2.00 & 11.20 & 1.80 & 0.00 & 0.00 & 279.6 & \\
\hline & SE & 93.01 & 3.90 & 22.21 & 6.61 & 7.40 & 0.00 & 2.00 & 9.58 & 2.39 & 0.00 & 0.00 & 109.1 & 39.02 \\
\hline \multirow{2}{*}{ MP $30 \mathrm{~m}$} & $X$ & 451.00 & 2.25 & 80.75 & 20.50 & 1.25 & 0.00 & 5.00 & 1.75 & 0.75 & 0.00 & 0.25 & 563.5 & \\
\hline & SE & 186.74 & 2.24 & 68.48 & 9.47 & 5.28 & 0.00 & 4.46 & 6.95 & 1.76 & 0.00 & 0.30 & 244.3 & 43.35 \\
\hline \multirow{2}{*}{ MP $60 \mathrm{~m}$} & $X$ & 357.00 & 6.75 & 2.25 & 8.50 & 4.50 & 0.00 & 3.50 & 7.00 & 4.75 & 0.25 & 0.00 & 394.5 & \\
\hline & SE & 151.03 & 3.65 & 32.60 & 7.73 & 3.23 & 0.00 & 3.51 & 4.47 & 3.59 & 0.30 & 0.14 & 188.7 & 47.83 \\
\hline
\end{tabular}


Table 2 - Mini Box Corer GEAMB total results (10 first centimeters of the sediment), converted for number of individuals in $0.056 \mathrm{~m} 2$ (X: mean; SE: standard error; $\mathrm{CV}$ : coefficient of variance; n: 3 ); CF: Comandante Ferraz station; MP: Machu Picchu station.

\begin{tabular}{|c|c|c|c|c|c|c|c|c|c|c|c|c|c|c|}
\hline & & Polychaeta & Nematoda & Oligochaeta & Cumacea & Gammaridae & Isopoda & Tanaidacea & Bivalvia & Gastropoda & Ostracoda & Others & Total & $\mathrm{CV}$ \\
\hline \multirow{2}{*}{$\mathrm{CF} 20 \mathrm{~m}$} & $\mathrm{X}$ & 2923.84 & 328.28 & 641.22 & 147.27 & 273.06 & 15.34 & 0.00 & 36.82 & 0.00 & 52.16 & 3.07 & 4421.06 & \\
\hline & SE & 2236.70 & 184.39 & 228.69 & 0.00 & 130.27 & 19.16 & 0.00 & 9.20 & 0.00 & 66.58 & 5.31 & 2508 & 56.73 \\
\hline \multirow{2}{*}{ CF $30 \mathrm{~m}$} & $\mathrm{X}$ & 205.56 & 9.20 & 0.00 & 46.02 & 27.61 & 0.00 & 0.00 & 21.48 & 0.00 & 6.14 & 141.13 & 457.14 & \\
\hline & SE & 74.40 & 9.20 & 0.00 & 24.35 & 31.88 & 0.00 & 0.00 & 21.26 & 0.00 & 10.63 & 125.64 & 83.01 & 18.16 \\
\hline \multirow{2}{*}{ CF $60 \mathrm{~m}$} & $\mathrm{X}$ & 156.47 & 0.00 & 0.00 & 12.27 & 0.00 & 0.00 & 6.14 & 0.00 & 0.00 & 0.00 & 0.00 & 174.88 & \\
\hline & SE & 18.41 & 0.00 & 0.00 & 5.31 & 0.00 & 0.00 & 5.31 & 0.00 & 0.00 & 0.00 & 0.00 & 18.41 & 10.53 \\
\hline \multirow{2}{*}{ MP 20m } & $\mathrm{X}$ & 2340.91 & 1076.88 & 527.70 & 174.88 & 128.86 & 0.00 & 12.27 & 12.27 & 9.20 & 18.41 & 6.14 & 4307.52 & \\
\hline & SE & 922.45 & 177.76 & 59.89 & 64.43 & 127.87 & 0.00 & 21.26 & 14.06 & 9.20 & 24.35 & 5.31 & 1284.52 & 29.82 \\
\hline \multirow{2}{*}{ MP $30 \mathrm{~m}$} & $\mathrm{X}$ & 2077.06 & 227.03 & 122.72 & 144.20 & 52.16 & 0.00 & 9.20 & 3.07 & 3.07 & 6.14 & 9.20 & 2653.85 & \\
\hline & SE & 739.16 & 67.84 & 107.86 & 55.48 & 32.32 & 0.00 & 0.00 & 5.31 & 5.31 & 5.31 & 9.20 & 577.76 & 21.77 \\
\hline \multirow{2}{*}{ MP $60 \mathrm{~m}$} & $\mathrm{X}$ & 374.30 & 168.74 & 36.82 & 82.84 & 79.77 & 6.14 & 3.07 & 18.41 & 9.20 & 15.34 & 3.07 & 797.7 & \\
\hline & SE & 50.69 & 78.28 & 48.70 & 87.80 & 10.63 & 10.63 & 5.31 & 31.88 & 9.20 & 10.63 & 5.31 & 184.16 & 23.09 \\
\hline
\end{tabular}

Significant differences $(\mathrm{p}<0.05)$ among density values from samples collected using both gears in 20,30 and $60 \mathrm{~m}$ at MP, and in $20 \mathrm{~m}$ depth at CF (Tables 1 and 2, Fig. 4). Van Veen samples underestimated total density in four out of six sampling stations (Fig. 4). Regarding the first two centimeters of sediment data, densities obtained with the van Veen were not significantly different from those collected with the MBC in five out of six study stations (Tables 1 and 3, Fig. 5). Furthermore, taxa composition in van Veen samples was similar to the top 2-cm samples collected with the MBC (Tables 1 and 3).The coefficient of variation of van Veen replicates was higher than that found for the MBC in all $\mathrm{CF}$ stations except for 20m depth station (Tables 1 and 2) indicating a lower sampling precision for the van Veen. Densities of benthic organisms collected with the MBC-GEAMB were ca. $60 \%$ higher considering all taxonomic groups. Mean of coefficient of variation was rather larger for van Veen replicates $(58.8 \%$ ) than for MBC subsamples (26.7\%) (Tables 1 and 2).

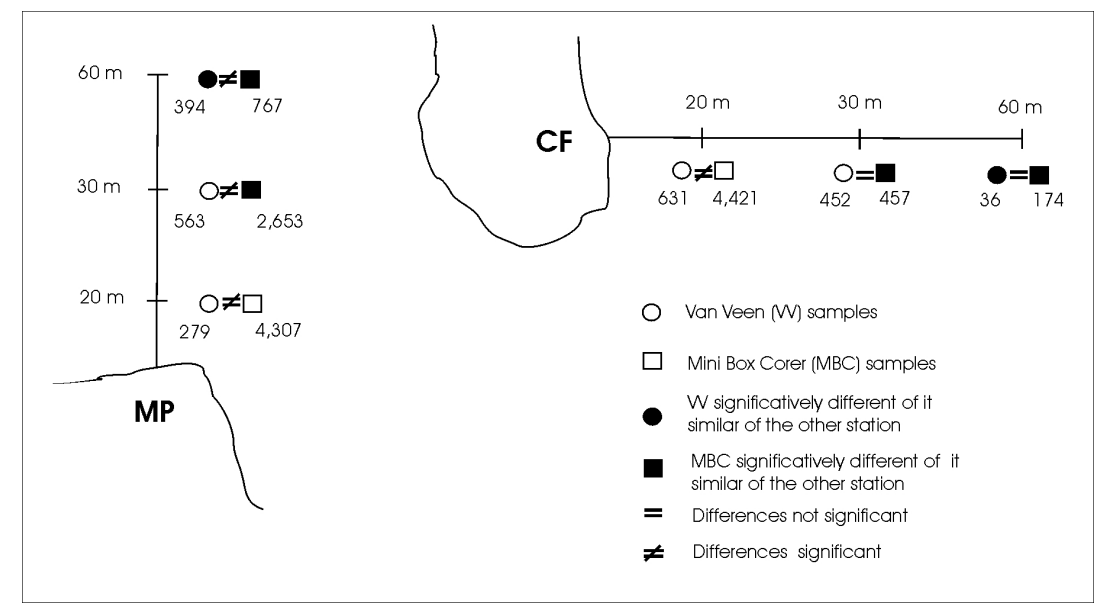

Figure 4 - MBC (10 first centimeters of sediment) samples compared to van Veen samples. Numbers under symbols are mean individuals $0.056 \mathrm{~m}^{-2}$ for each equipment. MBC samples resulted in more individuals $0.056 \mathrm{~m}^{-2}$ in all the stations (Fig. not in scale). 


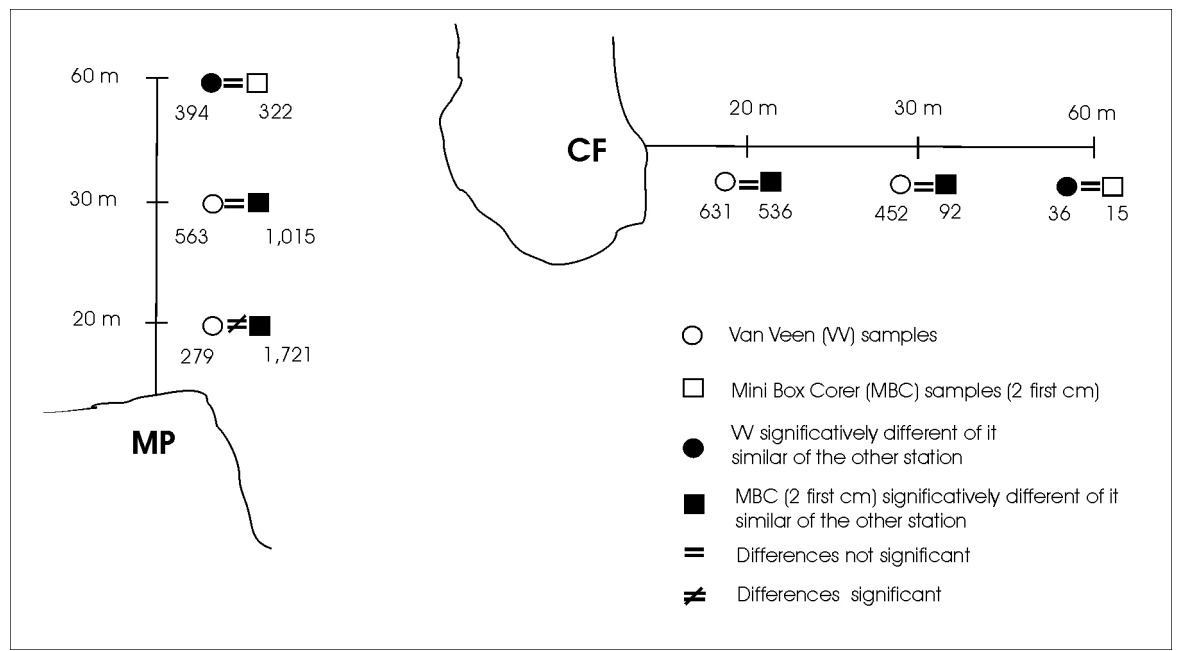

Figure 5 - MBC (2 first centimeters of sediment) samples compared to van Veen samples. Numbers under symbols are mean individuals $0.056 \mathrm{~m}^{-2}$ for each equipment. First two centimeters of sediment, collected with the MBC, are comparable to the entire van Veen samples in almost all the stations, except Machu Picchu at 20 meters depth (Fig. not in scale).

\section{DISCUSSION}

The van Veen grab is a common device used in benthic studies worldwide, including polar sediments (Richardson and Hedgepath, 1974, Jazszewski et al., 1986, Stark, 2000, WlodarskaKowalczuk and Pearson, 2004). It collects more effectively mainly the fauna that lives fairly close or associated to the surface sediments (e.g. small molluscs, amphipods, cumaceans). Nonetheless, compared to the MBC samples, the macrofauna was undersampled by the van Veen grab, owing to the limited penetration of this gear, as revealed by the similar densities observed when only the first 2 $\mathrm{cm}$ of sediment collected by the MBC was compared to the entire van Veen sample. Furthermore, even when sampling only the first 2 $\mathrm{cm}$ of the sediment, the MBC allowed for discrimination between sites at 20 and $30 \mathrm{~m}$ depth, which was not possible when van Veen was employed, hence suggesting a better sampling resolution for the MBC. Somerfield and Clarke (1997) assessed the efficiency of van Veen, Box Corer and diver- operated corers sampling the same bottom fauna, concluding that diver-operated corers perfomed better than remote sampling gears owing to the lower multivariate variance among the replicates. Based on the same variance criteria, these authors also concluded that box corer performed better than van Veen grabs, although differences among the three methods could not be detected when univariate statistical methods were employed. The present results showed significant differences between MBC and van Veen even when employing univariate analysis. This indicated a higher performance from the MBC when sampling shallow water Antarctic communities

Besides higher sampling performance, SCUBA diving in Antarctica did not become as important as it was expected in the past (Arntz et al., 1994). Although this activity is widely used in marine biology since the 1950s, logistics and safety considerations limit the investigations using this technique in Antarctica, being also restricted to shallow zones (Clarke, 1996). The main advantage of this remote-sampling device is that it has been dimensioned for operation from small boats with a winch, which becomes very important in Antarctic shallow marine sediment studies. Owing to the narrow Antarctic continental shelf, a pronounced slope from the shallow to the bottom implies that larger vessels with low maneuverability can only operate safely at deeper waters, usually below 100m deep (Sáiz-Salinas et al., 1997, Gambi and Bussotii, 1999, Pieenburg et al., 2002). Another advantage of using the MBC is that subsamples for many different analyses can be carried out from each sample, allowing a direct inference from several parameters in integrated environmental studies and monitoring programs. This advantages are not available even using a larger (i.e. $0.1 \mathrm{~m}^{2}$ ) 
van Veen, capable of sampling a similar area as the MBC. Deep of penetration, even in a larger and heavier van Veen, is not easily determined, and in this way the use of the volume of the sample can lead to an error of density estimation. The area of catch of a van Veen is relatively constant (is the area of the sampler wide opened when it reaches the bottom); the volume of the sample is variable as a function of its penetration depth, which depends on the sediment compactation, the grab vertical speed, etc. As benthic density is calculated as the number of individuals per sampling area of the grab, and as the organisms are not evenly distributed vertically on the sediment, a van Veen small volume sample tends to overestimate the communities density when is corrected by the volume. This occurs because most of the benthic organisms are located near the surface of the sediment, and even a bad catch (with a small volume of sediment) with a van Veen samples exactly this organism rich surface. A deeper sample with the same van Veen catches more sediment but not a proportional density of organisms, as deeper sediment bears much less organisms. In this way, the MBC allows to sample an exact volume of the sediment, and also to determine the vertical distribution of organisms, avoiding sampling problems of the van Veen.

\section{ACKNOWLEDGEMENTS}

The authors wish to thank to SeCIRM and CNPq which provided grant and logistic support in the scope of the Brazilian Antarctic Program (PROANTAR). Thanks to one anonymous referee for valuable comments and suggestions.

\section{RESUMO}

Um novo Mini Box Corer (MBC-GEAMB) foi desenvolvido para amostragens de fundo em águas rasas antárticas até 100 metros de profundidade, a partir de embarcações pequenas. Consiste em uma caixa de aço inox destacável com uma área total de amostragem de $0,0625 \mathrm{~m}^{2}$, e um braço de fechamento com uma lâmina destacável, sem um suporte externo. MBC permite a amostragem estratificada do sedimento de fundo com amostras de qualidade comparáveis àquelas obtidas através de mergulho autônomo. Uma comparação entre o MBC-GEAMB e um van Veen de área $0,056 \mathrm{~m}^{2}$ (VV) foi realizada utilizando a composição da macrofauna bentônica na Baía do Almirantado, (Ilha Rei George, Antarctica). Amostragens com MBC e VV foram realizadas em três profundidades $(20,30$ e $60 \mathrm{~m})$ em dois locais. As densidades totais obtidas com o MBC foram até 10 vezes maiores que as obtidas com o van Veen. Amostragens com VV tendem a subamostrar a abundância faunística em comparação com amostragens realizadas com o MBC. O MBC apresentou melhor capacidade de resolução para discriminar locais diferentes em relação à densidade total da macrofauna. O MBC pode ser utilizado como um amostrador remoto eficiente em águas rasas onde a amostragem por mergulho não é plausível.

\section{REFERENCES}

Arntz, W. E., Brey, T. and Gallardo, V. (1994), Antarctic Zoobenthos. Oceanogr. Mar.Biol. Ann. Rev., 32, 241-304.

Bromberg, S. (1999), Distribuição dos anelídeos poliquetas na zona costeira rasa da Enseada Martel, Baía do Almirantado (Ilha Rei George- Antártica). M.Sc thesis, Univesity of São Paulo, São Paulo, Brazil.

Clarke, A. (1996), Benthic marine habitats in Antarctica. In-Foundations for ecological research west of the Antarctic Peninsula, ed. R.M. Ross, E.E. Hofmann and L.B. Quetin. American Geophysical Union. Antarctic Research Series, Cambridge, Vol.70. pp. 123-133.

Eleftheriou, A. and Holme, N. A. (1984). Macrofauna techniques. In-Methods for the study of marine benthos, ed.N.A. Holme, and A. D. McIntyre. Blackwell Scientific Publications, Oxford, pp. 140216.

Fonseca, A. L. S., Minello, M., Marinho, C. C. and Esteves, F. A. (2004), Methane Concentration in Water Column and in Pore Water of a Coastal Lagoon (Cabiúnas Lagoon, Macaé, RJ, Brazil). BABT 47-2, $301-308$.

Gambi, M. C., and Bussoti, S. (1999), Composition, abundance and stratification of soft-bottom macrobenthos from selected areas of the Ross Sea shelf (Antarctica). Pol. Biol., 21, 347-354.

Hessler, R. R., and Jumars, P. A. (1974), Abyssal community analysis from replicate box cores in the central North Pacific. Deep Sea Res. Oceanogr. Abstr., 21, 185-209. 
Holme, N. A., and McIntyre, A. D. (1984), Methods for the study of marine benthos. 2nd ed. Blackwell Scientific, Oxford.

Jazdzewski, K.; Jurasz, W.; Kittel, W.; Pressler, E..; Pressler. P, and Sicinski, J. (1986), Abundance and biomass estimates of benthic fauna in Admiralty bay, King George Island, South Shetlands Islands. Pol. Biol., 6, 5-16.

Jazdzewski, Z. (1998), Zoobenthos of Admiralty Bay in King Geroge Island, South Shetland Islands. Pesq. Ant. Bras., 3, 1-7.

Nonato, E. F.; Brito, T. A. S.; Paiva, P. C.; Petti, M. A. V. and Corbisier, T. N. (2000), Benthic megafauna of the nearshore zone of Martel Inlet (King George Island, South Shetland Islands, Antarctica): depth zonation and underwater observations. Pol. Biol., 23, 580-588.

Piepenburg, D.; Schmid, M. K. and Gerdes, D. (2002), The benthos off King George Island (South Shetland Islands, Antarctica): further evidence for a lack of a latitudinal biomass cline in the Southern Ocean. Pol. Biol., 25, 146-158.

Richardson, M. D., and Hedgepeth, J. W. (1974), Antarctic soft-bottom, macrobenthic community adaptations to a cold, stable, highly productive, glacially affected environment. In- Adaptations within Antarctic Ecosystems. Proceedings of the Third SCAR Symposium on Antarctic Biology, ed. Llano, G. A. (ed), Washington DC. pp. 181-196.

Sáiz-Salinas, J. I.; Ramos, A.; Garcia, F. J.; Troncoso, J. S.; San Martin, G.; Sanz, C. and Palacin C. (1997),
Quantitative analysis of macrobenthic soft-bottom assemblages in South Shetland waters (Antarctica). Pol. Biol., 17, 393-400.

Santos Furtado, A. L., Casper, P. and Esteves, F.A. (2002), Methanogenesis in an Impacted and Two Dystrophic Coastal Lagoons (Macaé, Brazil). BABT, 45-2, 195 - 202.

Skowronski, R. S. P.; Corbisier, T. N. and Robles, F. R. (1998), Meiofauna along a coastal transect in Admiralty bay, King George Island (Antarctica). Pesq. Ant. Bras., 3, 117-132.

Somerfield, P. J. and Clarke, K. R. (1997), A comparison of some methods commonly used for the collection of sublittoral sediments and their associated fauna. Mar. Environ. Res., 43, 145-156.

Stark, J. S. (2000), The distribution and abundance of soft-sediment macrobenthos around Casey Station, East Antarctica. Pol. Biol., 23, 840-850.

Underwood, A.J. (1997), Experiments in ecology: their logical design and interpretation using analysis of variance. Cambridge University Press, Cambridge.

Wlodarska-Kowalczuk, M. and Pearson, T. H. (2004), Soft-bottom macrobenthic faunal associations and factors affecting species distribution in an Arctic glacial fjord (Kongsfjord, Spitsbergen). Pol. Biol., 7, 155-16.

Received: September 27, 2006; Revised: April 20, 2007; Accepted: August 04, 2008. 